\title{
Peripheral Ossifying Fibroma : A Very Rare Clinical Presentation
}

\author{
Shaik Hasanuddin ${ }^{1}$, P. Raja Babu' \\ ${ }^{1}$ Department of Pedodontics and Preventive Dentistry, Government Dental College and Hospital, Hyderabad, Telangana, India, \\ ${ }^{2}$ Department of Periodontics, Kamineni Institute of Dental Sciences, Narketpally, Nalgonda, Telangana, India
}

Email for correspondence: dr.hasan.shaik@gmail.com

\begin{abstract}
The use of the term "fibroma" for any soft tissue lesion or gingival lesion by general practitioners has led to an inadequate diagnosis of quite a few rare entities. The occurrence of gingival lesions in adolescent female patients is a routine clinical finding. The site of occurrence of such a lesion is of prime significance, as the rarity of these lesions is determined by the site and size of the lesion. On the other hand, the dilemma over the diagnosis of peripheral ossifying fibroma (POF) versus peripheral odontogenic fibroma still continues. Commonly used synonyms for POF include calcifying fibroblastic granuloma, peripheral fibroma with calcification, peripheral cementifying fibroma, and calcifying, or ossifying fibrous epulis. The present case report deals with a unique case of POF between two maxillary central incisors in an adolescent female child patient and its surgical treatment, with 2 years of follow-up.
\end{abstract}

Key words: Fibroma, peripheral odontogenic fibroma, peripheral ossifying fibroma

\section{INTRODUCTION}

The occurrence of gingival lesions in young female adolescents is a routine clinical finding, but the site of such lesions determines their rarity. The extensive use of the term 'fibroma' with regard to the diagnosis of a swelling or lump on the oral mucosa and gingiva has often being misleading for young dentists. The diagnosis of peripheral ossifying fibroma (POF) versus peripheral odontogenic fibroma in young children is often being debated since a long time. The origin of the lesion in most of these cases is from the interdental papilla, which is often intimately related to inflammatory fibrous hyperplasia. ${ }^{[1]}$

\section{CASE REPORT}

A 15-year-old teenage girl had reported to our department with a chief complaint of an unusual

\begin{tabular}{|l|l|}
\hline Quick Response Code & Article Info: \\
\hline doi: 10.5866/2017.9.10197 \\
$\begin{array}{l}\text { Received: } 23-07-2017 \\
\text { Revised: } 28-08-2017 \\
\text { Accepted: } 12-09-2017 \\
\text { Available Online: } 27-11-2017 \text { (www.nacd. } \\
\text { in)@ NAD, 2017 - All rights reserved }\end{array}$ \\
\hline
\end{tabular}

swelling in the anterior maxillary region with lip incompetency. The history revealed that the gingival growth has increased in size rapidly in the past 6 -month period with no visible clinical, etiologic factor. The teeth around the lesion were vital and the response to vitality tests was positive.

Clinically, the lesion appeared as an elevated mass of pale pink color with a smooth surface and a sessile base with a well-defined margin originating from labial gingiva in relation to the maxillary central incisors. The size of the lesion was $2420 \mathrm{~mm}$ causing displacement of the incisors [Figure 1]. Consistency was firm and resilient. Radiographically, there was no definite radiolucency in relation to both the central incisors. OPG revealed no signs of bony involvement.

The lesion was excised surgically involving the peripheral border [Figures 2 and 3] and sutured with black silk [Figure 4]. The excised specimen [Figure 5] was then sent for histopathological evaluation to the department of pathology. Histopathological report of the lesion revealed fibrous connective tissue containing bundles of collagen fibers and plump fibroblasts. Few areas revealed calcifications, irregularly shaped trabeculae and droplets of basophilic cementum-like material. 


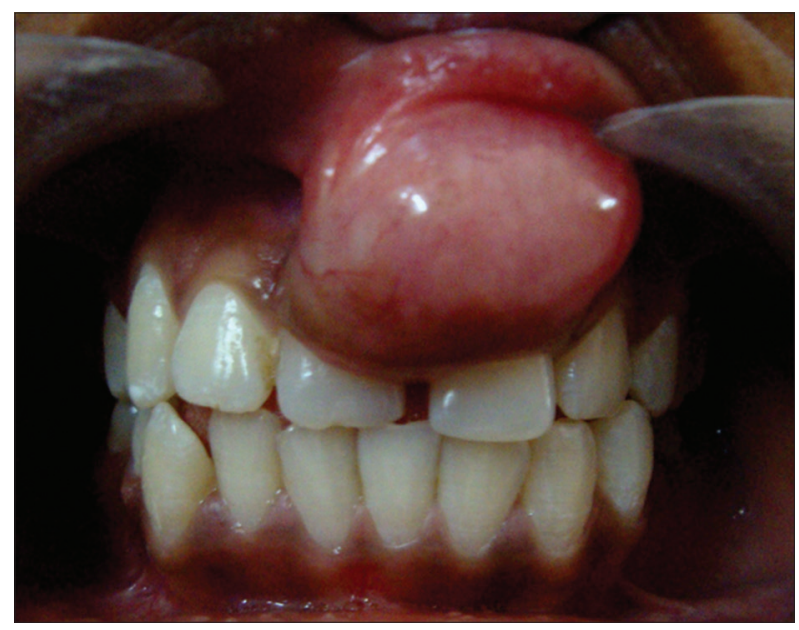

Figure 1: Clinical picture showing pre-operative image of the lesion obliterating the labial frenum, causing displacement of incisors

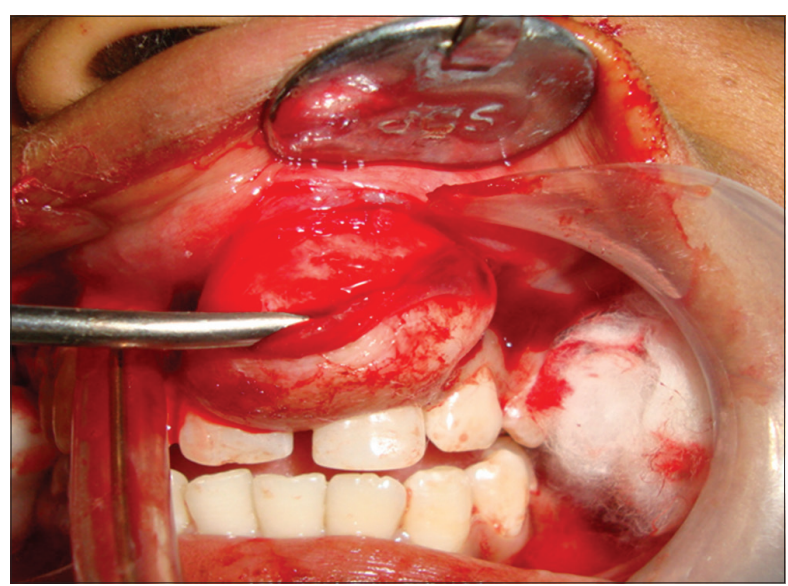

Figure 2: Operative picture showing the thick periosteal layer covering the nodular mass

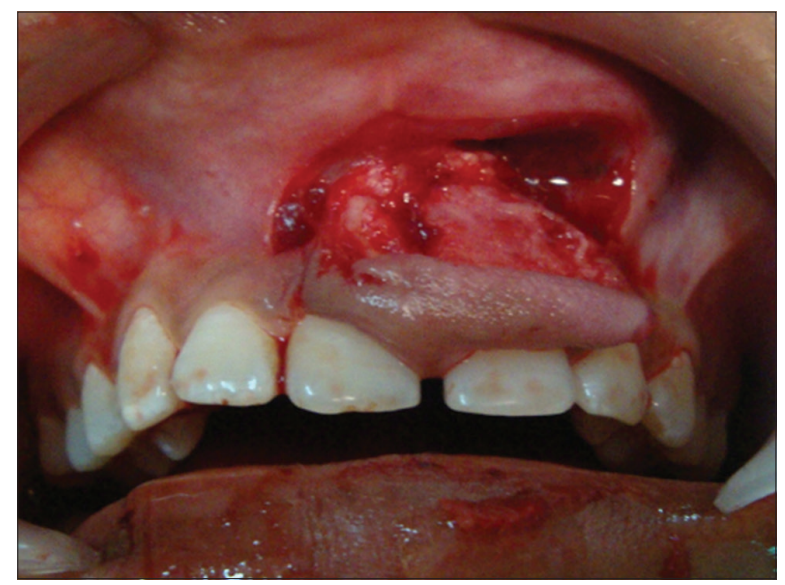

Figure 3: Picture showing the site of the excised lesion after surgical excision exposing the labial plate

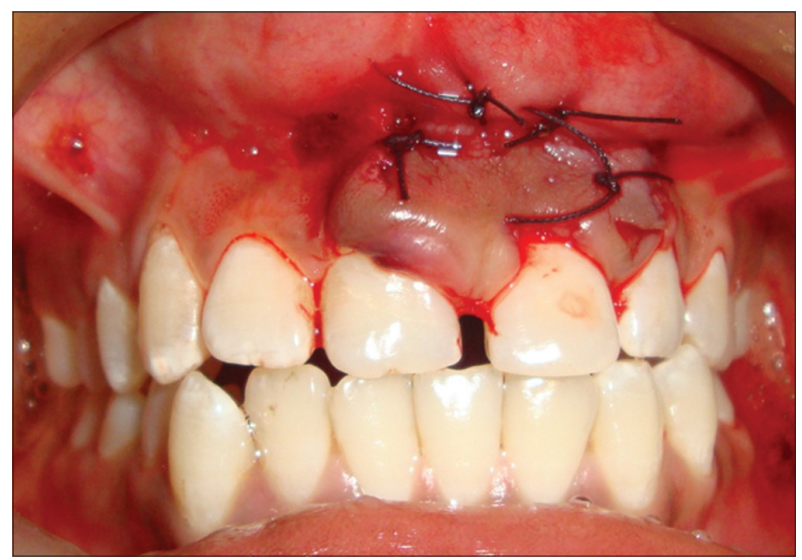

Figure 4: The post-operative image after suturing with black silk.

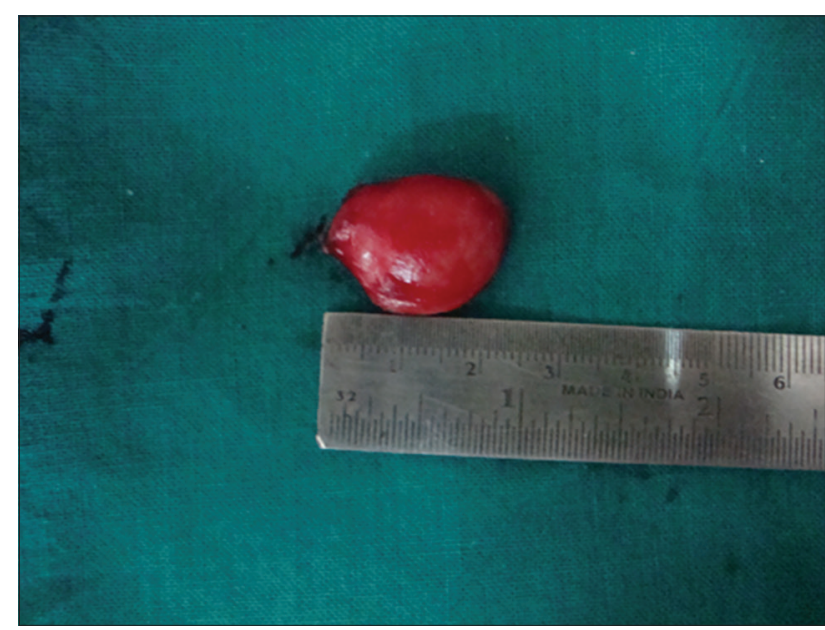

Figure 5: Specimen of the excised lesion

Basing on the clinical and histopathological findings the case has been diagnosed as POF. After 2 years of follow-up, there was no recurrence of the lesion at the excised site and also in other areas in the oral cavity.

\section{DISCUSSION}

POF was first reported by the Shepherd in 1844 as alveolar exostosis. ${ }^{[2]}$ The term "POF" was coined by Eversol and Rovin in 1972. ${ }^{[3]}$ It occurs exclusively on gingiva, usually arising from the interdental papilla, supposed to be derived from periodontal ligament. ${ }^{[1]}$ The site of the lesion is always anterior to the $1^{\text {st }}$ permanent molar, and $50 \%$ cases occur in incisor and canine region. ${ }^{[4]}$ In the present case, the lesion is present in between the two maxillary central incisors, causing slight displacement of both the teeth. The occurrence of the lesion in such a site 
is quite rare, which makes this case report very rare.

POF has a peak incidence in young and teenaged females. Cundiff reported that the lesion is prevalent between the age of 5 and 25 years with a peak incidence at 13 years of age. He also reported a definite female predilection. ${ }^{[5]}$ In the present case, the age of the female child was 14 years. Clinically, the lesion appears as nodular mass, which may be pedunculated or sessile, pink to red in color and surface is rarely ulcerated. ${ }^{[1]}$ In the present case, the lesion is sessile; surface is smooth and nonulcerated.

$\mathrm{POF}$ is considered to be reactive in nature rather than neoplastic. ${ }^{[6]}$ It is interesting to note that the fibroma, a true neoplasm of connective tissue origin, is microscopically similar to the condition known as inflammatory hyperplasia, an increased bulk of connective tissue which forms as part of an inflammatory reaction. The distinction between the two general processes, hyperplasia and neoplasia, is poorly defined in such cases. Hyperplastic tissues sometimes but not invariably regresses after removal of the stimulus or the irritant. Neoplastic tissues show no such regressions. However, processes of hyperplasia and neoplasia may not be as completely disassociated as previously considered and that a true oral neoplasm may result from chronic irritation. ${ }^{[6]}$ However, in the present case, there was no source of any chronic irritation in relation to both the central incisors. POF is characterized by a high degree of cellularity usually exhibiting bone formation, although occasionally cementum such as material or dystrophic calcification may also be formed.

Differential diagnosis in such cases is essential, due to the clinical relevance to many other similar lesions and POF's tendency to recur. ${ }^{[7]}$ Histopathological examination is essential for accurate diagnosis. Differential diagnosis includes peripheral odontogenic fibroma, pyogenic granuloma, peripheral giant cell granuloma, peripheral ameloblastoma, and calcifying epithelial odontogenic tumor.

The peripheral odontogenic fibroma (WHO type) is a relatively rare, benign, unencapsulated, exophytic gingival mass of fibrous connective tissue. According to the present concept, cases reported in literature under the terms "odontogenic gingival epithelial hamartoma" "hamartoma of the dental lamina" and "peripheral ameloblastic fibrodentinoma" are actually examples of peripheral odontogenic fibroma. ${ }^{[8]}$ The peripheral odontogenic fibroma must be differentiated histologically from POF, which is a reactive lesion, and from the peripheral ameloblastoma and the calcifying epithelial odontogenic tumor which are benign odontogenic tumors. ${ }^{[8]}$ In the present case, the lesion is sessile and encapsulated by a thick periosteum. Hence, it is excluded from peripheral odontogenic tumor, pyogenic granuloma, and epulis/papilloma. Both pyogenic granulomas and pregnancy epulis may mature and become less vascular and more collagenous, gradually converting to fibrous epulis. ${ }^{[1]}$ There is no doubt that the pyogenic granuloma if left untreated will undergo eventual healing by sclerosis and will then microscopically resemble the POF.

Gingival and periodontal lesions in children are quite rare. However, in teenage adolescent female patients, the incidence of gingival lesions in the second decade of life is quite high due to the hormonal effect on the gingival tissues. Pediatric patients with such a lesion have special management considerations as it requires early recognition and treatment. It requires proper treatment protocol with close post-operative follow-up.

\section{REFERENCES}

1. Greenberg MS, Glick M. Burket's Oral Medicine-Diagnosis and Treatment. $10^{\text {th }}$ ed. Ch. 7. Philadelphia, PA: Wilkins 2013. p. 142

2. Reddy GV, Reddy J, Ramlal G, Ambati M. Peripheral ossifying fibroma: Report of two unusual cases. Indian J Stomatol 2011;2:130-3

3. Eversole LR, Rovin S. Reactive lesions of the gingiva. J Oral Pathol 1972;1:30-8.

4. Neville BW, Damm DD, Allen CM, Bouquot JE. Oral and Maxillofacial Pathology. $2^{\text {nd }}$ ed. New Delhi: Elsevier; 2005. p. 563-4.

5. Cundiff EJ. Peripheral Ossifying Fibroma: A Review of 365 Cases, MSD Thesis. USA: Indiana University; 1972.

6. Shafer WG, Hine MK, Levy BM. A Textbook of Oral Pathology. $4^{\text {th }}$ ed. Ch. 2. Philadelphia, PA: WB. Saunders Company; 1983. p. 139.

7. Gardner DG. The peripheral odontogenic fibroma: An attempt at clarification. Oral Surg Oral Med Oral Pathol 1982;54:40-8.

8. Buchner A. Peripheral odontogenic fibroma. Report of 5 cases. J Craniomaxillofac Surg 1989;17:134-8. 